(6)

\section{OPEN ACCESS}

Advanced Lung Disease and Lung Transplantation, Inova Fairfax Hospital, Falls Church, Virginia, USA

Correspondence to Dr Christopher King, christopher.king@inova.org

Accepted 22 September 2018

\title{
Fungal thyroiditis in a lung transplant recipient
}

\section{Christopher King, Stephen Clement, Shalika Katugaha, Anne Whitney Brown}

\section{DESCRIPTION}

A 59-year-old man was admitted with 3 weeks of worsening shortness of breath 18 months after receiving

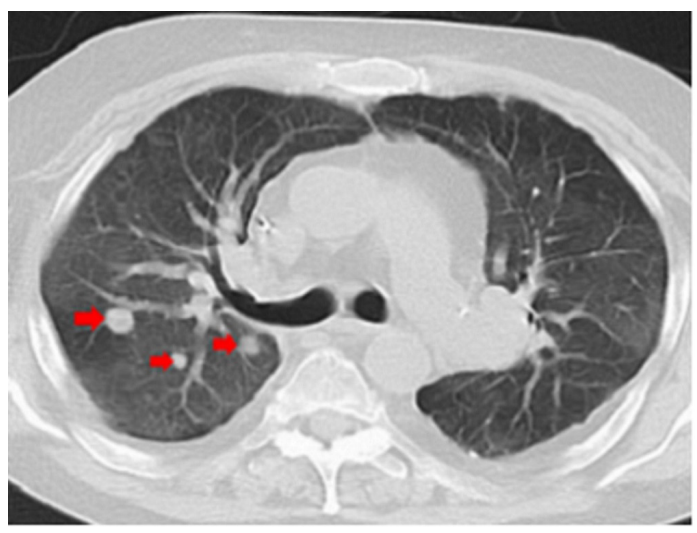

Figure 1 Chest CT showing multiple pulmonary nodules in the right lower lung field (red arrows).

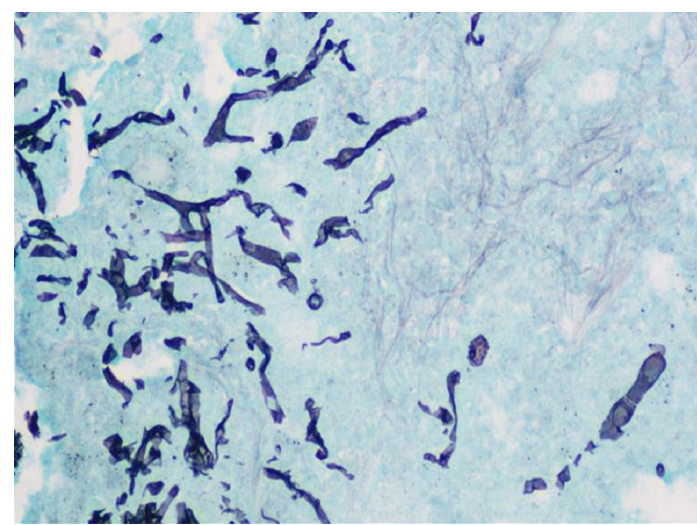

Figure 2 Fungal hyphae are present on Gomori Methenamine-Silver (GMS) stain from CT-guided lung biopsy (x200).

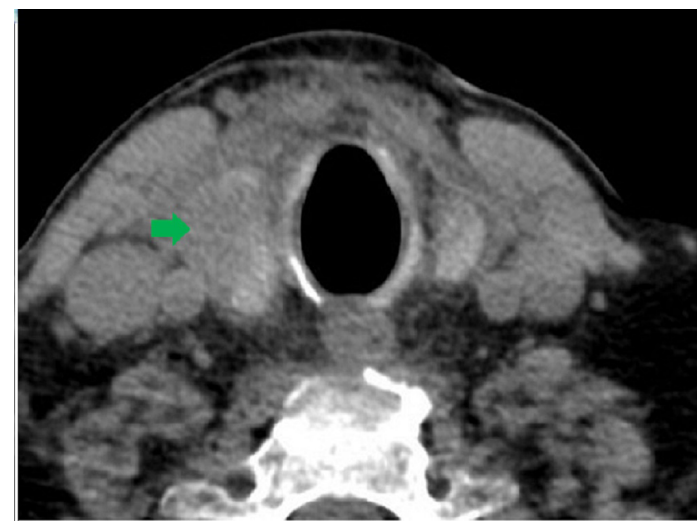

Figure 3 CT of the neck revealed a mass-like lesion in the right lobe of the thyroid (green arrow). a bilateral lung transplant for idiopathic pulmonary fibrosis. His immunosuppression included tacrolimus, everolimus and low-dose prednisone with no antifungal prophylaxis at the time of admission. CT chest revealed multiple, bilateral pulmonary nodules (figure 1-red arrows). CT-guided biopsy revealed fungal hyphae (figure 2). The initial CT and ultrasound of the neck at the onset of sore throat was negative; however, repeat CT neck for evolving neck pain and dysphasia during hospital course showed a masslike lesion in the right thyroid lobe with extensive surrounding inflammatory changes (figure 3-green arrow). The lesion was also visualised on ultrasound, where it appeared as a hypoechoic solitary nodule (figure 4). Laboratory evaluation revealed hyperthyroidism, with a Thyroid Stimulating Hormone (TSH) of $<0.01 \mu \mathrm{IU} / \mathrm{mL}$ (normal: $0.35-4.94 \mu \mathrm{IU} / \mathrm{mL}$ ) and a free T4 of $2.72 \mathrm{ng} / \mathrm{dL}$ (normal: $0.70-1.48 \mathrm{ng} / \mathrm{dL}$ ). The patient was initiated on dual antifungal therapy with liposomal amphotericin and posaconazole, resulting in rapid resolution of neck pain. However, repeat CT neck 2 weeks after revealed a thyroid abscess in the

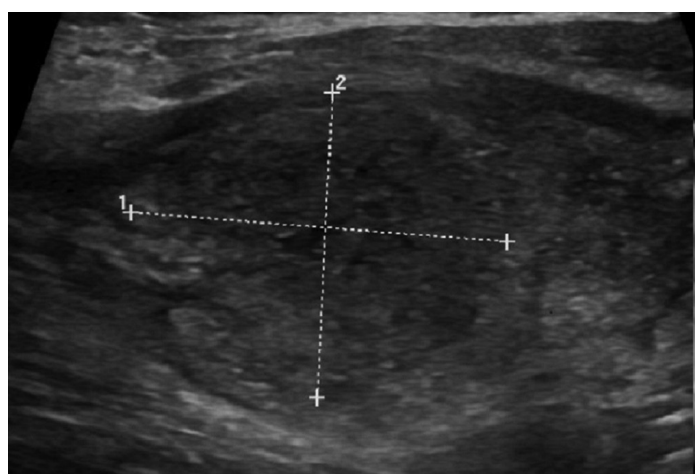

Figure 4 Thyroid ultrasound reveals a $2.8 \times 2.3 \mathrm{~cm}$ hypoechoic lesion in the right thyroid isthmus.

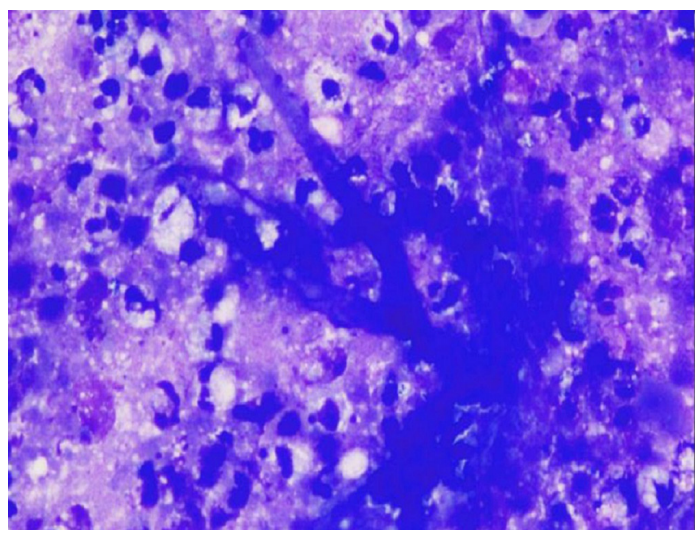

Figure 5 Fungal hyphae were present in the necrotic material from the thyroid abscess debridement $(H \& E$, $\mathrm{x} 400)$. 
right lobe, and subsequently the patient underwent right thyroid lobectomy and isthmusectomy. Surgical debridement of the thyroid abscess revealed fungal hyphae; thus, confirming the diagnosis of fungal thyroiditis (figure 5). A specific fungal pathogen was never successfully cultured from our patient. He was treated for presumed

\section{Learning points}

- Thyroiditis is a rare manifestation of disseminated fungal infection in immunocompromised hosts.

- Aspergillus spp are the most commonly implicated pathogen, although there are reports of cases due to Cryptococcus neoformans, Histoplasma capsulatum, Coccidioides immitis and Candida spp.

- Antifungal therapy targeting the culprit organism and consideration of surgical debridement are the mainstays of treatment.
Aspergillus infection, the most common etiology of fungal thyroiditis, with clinical improvement. ${ }^{1}$

Acknowledgements Haresh Mani, MD Min Kim, MD.

Contributors CK, SK and AWB: planning, writing, revision. SC: planning, revision.

Funding The authors have not declared a specific grant for this research from any funding agency in the public, commercial or not-for-profit sectors.

Competing interests None declared.

Patient consent Obtained.

Provenance and peer review Not commissioned; externally peer reviewed.

Open access This is an open access article distributed in accordance with the Creative Commons Attribution Non Commercial (CC BY-NC 4.0) license, which permits others to distribute, remix, adapt, build upon this work non-commercially, and license their derivative works on different terms, provided the original work is properly cited and the use is non-commercial. See: http://creativecommons.org/ licenses/by-nc/4.0/

\section{REFERENCE}

1 Goldani LZ, Zavascki AP, Maia AL. Fungal thyroiditis: an overview. Mycopathologia 2006:161:129-39.

Copyright 2018 BMJ Publishing Group. All rights reserved. For permission to reuse any of this content visit

http://group.bmj.com/group/rights-licensing/permissions.

BMJ Case Report Fellows may re-use this article for personal use and teaching without any further permission.

Become a Fellow of BMJ Case Reports today and you can:

- Submit as many cases as you like

- Enjoy fast sympathetic peer review and rapid publication of accepted articles

- Access all the published articles

Re-use any of the published material for personal use and teaching without further permission

For information on Institutional Fellowships contact consortiasales@bmjgroup.com

Visit casereports.bmj.com for more articles like this and to become a Fellow 